\title{
Modes of application of cobalt, molybdenum and Azospirillum brasilense on soybean yield and profitability
}

\author{
Fernando S. Galindoㄹ, Marcelo C. M. Teixeira Filho², Salatier Buzetti², \\ José M. K. Santini' ${ }^{1}$, Mariana G. Z. Ludkiewicz \& Guilherme Baggio ${ }^{1}$ \\ ${ }^{1}$ Universidade Estadual Paulista "Júlio de Mesquita Filho"/Faculdade de Engenharia de Ilha Solteira. Ilha Solteira, SP. E-mail: fs.galindo@bol.com.br \\ (Corresponding author); santinijmk@gmail.com; mariana.gaioto@gmail.com; baggio_guilherme@hotmail.com \\ ${ }^{2}$ Universidade Estadual Paulista “Júlio de Mesquita Filho"/Faculdade de Engenharia de Ilha Solteira/Departamento de Fitossanidade, Engenharia Rural \\ e Solos. Ilha Solteira, SP. E-mail: mcmtf@yahoo.com.br; sbuzetti@agr.feis.unesp.br
}

\section{Key words:}

co-inoculation with Azospirillum brasilense

total operating cost

economic viability

technical viability

leaf nitrogen content

\begin{abstract}
A B S T R A C T
The use of cobalt (Co) and molybdenum (Mo) along with the co-inoculation with Azospirillum brasilense on soybean can contribute to biological nitrogen fixation (BNF), allowing higher yields. Thus, this work aimed to study the technical and economic viability of soybean in the Cerrado, according to the mode of application of $\mathrm{Co}+\mathrm{Mo}$, and seed or leaf co-inoculation with Azospirillum brasilense. The experiment was conducted in SelvíriaMS, in a no-tillage system in an Oxisol, arranged in a randomized block design with six treatments (seed application of two treatments with $\mathrm{Co}+\mathrm{Mo}$, with or without inoculation with A. brasilense, respectively; Foliar application of Co + Mo at soybean V3 stage; Foliar application of $\mathrm{Co}+$ Mo together with A. brasilense at V3 growth stage; Foliar application of $A$. brasilense at V3 growth stage; and the Control, consisting of only inoculation with Rhizobium), and four replicates. Seed application of Co + Mo associated with seed inoculation with $A$. brasilense promoted the highest leaf $\mathrm{N}$ content, hundred-grain weight, yield and profitability with the soybean crop.
\end{abstract}

\section{Palavras-chave:}

coinoculação com Azospirillum brasilense custo operacional total viabilidade econômica viabilidade técnica concentração de nitrogênio foliar

\section{Modos de aplicação de cobalto, molibdênio e Azospirillum brasilense na produtividade e lucratividade da soja}

\begin{abstract}
R E S U M O
A utilização de cobalto (Co) e molibdênio (Mo) pode, juntamente com a coinoculação com Azospirillum brasilense na cultura da soja, contribuir na fixação biológica de nitrogênio (FBN), possibilitando maiores produtividades. Por esta razão, se objetivou estudar a viabilidade técnica e econômica da cultura da soja no Cerrado em função do modo de aplicação de cobalto e molibdênio e da coinoculação de sementes ou via foliar com Azospirillum brasilense. $\mathrm{O}$ experimento foi desenvolvido em Selvíria, MS, em sistema de semeadura direta, em Latossolo Vermelho distrófico, dispostos em delineamento experimental de blocos casualizados com seis tratamentos (aplicação via semente, em dois tratamentos de Co e Mo, com ou sem a inoculação com $A$. brasilense, respectivamente; aplicação via foliar de Co e Mo no estádio V3 da soja; aplicação via foliar de Co e Mo juntamente com A. brasilense no estádio V3; aplicação via foliar de A. brasilense no estádio V3 e a Testemunha, constando apenas da inoculação com bradirrizóbio) e quatro repetições. A aplicação de Co e Mo via semente associados à inoculação com $A$. brasilense da semente proporcionou a maior concentração de $\mathrm{N}$ foliar, massa de 100 grãos, produtividade e lucratividade com a cultura da soja.
\end{abstract}




\section{INTRODUCTION}

Due to the large nitrogen $(\mathrm{N})$ requirement by the crops to achieve high yields, $\mathrm{N}_{2}$ fixation must function with maximum efficiency (Figueiredo et al., 2008; Vieira Neto et al., 2008; Zilli et al., 2008; Hungria et al., 2010; Rodrigues et al., 2012; Ignácio et al., 2015; Bulegon et al., 2016). Besides using inoculant with Bradyrhizobium selected and efficient, cobalt (Co) and molybdenum (Mo) decisively contribute to the biological $\mathrm{N}_{2}$ fixation (BNF) (Dourado Neto et al., 2012), influencing the synthesis of leghemoglobin, which determines the activity of the nodules and, being a structural component of the nitrogenase, catalyzes the reduction of atmospheric $\mathrm{N}_{2}$ to $\mathrm{NH}_{3}$ (Bárbaro et al., 2009a; Golo et al., 2009).

Considering the main current and potential limitations of BNF in the soybean crop and the benefits attributed to the various crops by the inoculation with Azospirillum (free- living diazotrophic bacteria), especially the greater development of the root system and, consequently, also higher absorption of water and nutrients (Galindo et al., 2016), it is deduced that, with the co-inoculation in microorganism, there may be improvements in the performance of the crops in an approach that respects the current demands for agricultural, economic, social and environmental sustainability (Hungria et al., 2013).

It becomes necessary, in this context, to conduct studies that aim to increase BNF efficiency associating the mode of application of $\mathrm{Co}+\mathrm{Mo}$ with the co-inoculation of Bradyrhizobium and Azospirillum brasilense, allowing better use of water and nutrients, without causing reduction in yield or quality of agricultural products. However, there are not many studies in the literature that economically evidence the effect of co-inoculation with Azospirillum brasilense associated with the application of Co + Mo in the soybean crop.

Based on the above, this study aimed to evaluate the technical and economic viability of the soybean crop in the Cerrado, as a function of the mode of application of $\mathrm{Co}+\mathrm{Mo}$ and its coinoculation in seeds or leaves with Azospirillum brasilense.

\section{Material AND Methods}

The research was carried out at the experimental area of the Faculty of Engineering - UNESP, located in Selvíria, MS,
Brazil, at altitude of $335 \mathrm{~m}$. The soil of the experimental area was classified as dystrophic Red Latosol with clayey texture, according to the classification of EMBRAPA (2013). This soil has been cultivated by annual crops for more than 27 years and, in the last 10 years, has been under no - tillage system, with maize as the previous crop. In this area, there is no history of artificial introduction of Azospirillum brasilense. The climatic type in the region is Aw, according to Köppen's classification, characterized as humid tropical with rainy season in the summer and dry season in the winter. The climate data recorded during the experimental period are shown in Figure 1.

The soil chemical attributes in the arable layer were determined before installing the experiment, according to the methodology proposed by Raij et al. (2001), showing the following results: $10 \mathrm{mg} \mathrm{dm}^{-3}$ of $\mathrm{P}$ (resin); $5 \mathrm{mg} \mathrm{dm}^{-3}$ of S-SO $22 \mathrm{~g} \mathrm{dm}^{-3}$ of OM; 5.3 of $\mathrm{pH}\left(\mathrm{CaCl}_{2}\right) ; \mathrm{K}, \mathrm{Ca}, \mathrm{Mg}, \mathrm{H}+\mathrm{Al}=2.4$; $21.0 ; 18.0$ and $28.0 \mathrm{mmol}_{\mathrm{c}} \mathrm{dm}^{-3}$, respectively; $\mathrm{Cu}, \mathrm{Fe}, \mathrm{Mn}, \mathrm{Zn}$ $(\mathrm{DTPA})=3.2 ; 22.0 ; 24.2$ and $1.2 \mathrm{mg} \mathrm{dm}^{-3}$, respectively; 0.16 $\mathrm{mg} \mathrm{dm}^{-3}$ of B (hot water) and $60 \%$ of base saturation. Based on the soil analysis and on the recommendation of fertilization for the soybean crop (Ambrosano et al., 1997), the fertilization at sowing was applied in the sowing furrow with $80 \mathrm{~kg} \mathrm{ha}^{-1}$ of $\mathrm{P}_{2} \mathrm{O}_{5}$ and $80 \mathrm{~kg} \mathrm{ha}^{-1}$ of $\mathrm{K}_{2} \mathrm{O}$.

The seeds were treated with the fungicides Carbendazim + Thiram at the dose of $30+70 \mathrm{~g}$ of a.i. for every $100 \mathrm{~kg}$ of seeds, respectively. After drying the seeds, they were inoculated with rhizobium at the dose of $200 \mathrm{~mL} \mathrm{ha}^{-1}$ (strains: SEMIA 5019 (Bradyrhizobium elkanii) and SEMIA 5079 (Bradyrhizobium japonicum), with guarantee of $5 \times 10^{9}$ of viable cells per $\mathrm{mL}$ ), inside a clean concrete mixer to incorporate them into the seeds. This procedure was performed one hour before soybean sowing.

The experiment was installed in December 2014, with mechanical sowing of the soybean cultivar 'BMX Potência $\mathrm{RR}$ ', at spacing of $0.45 \mathrm{~m}$ between rows, by planting 17 seeds per meter.

The experimental design was randomized blocks with six treatments and four replicates. The treatments were: 1) Control (soybean without inoculation with Azospirillum brasilense and without Co + Mo application); 2) Seed with Co + Mo application at the dose of $150 \mathrm{~mL} \mathrm{ha}^{-1}$ of the commercial product (15\% of Mo and $1.5 \%$ of Co), which

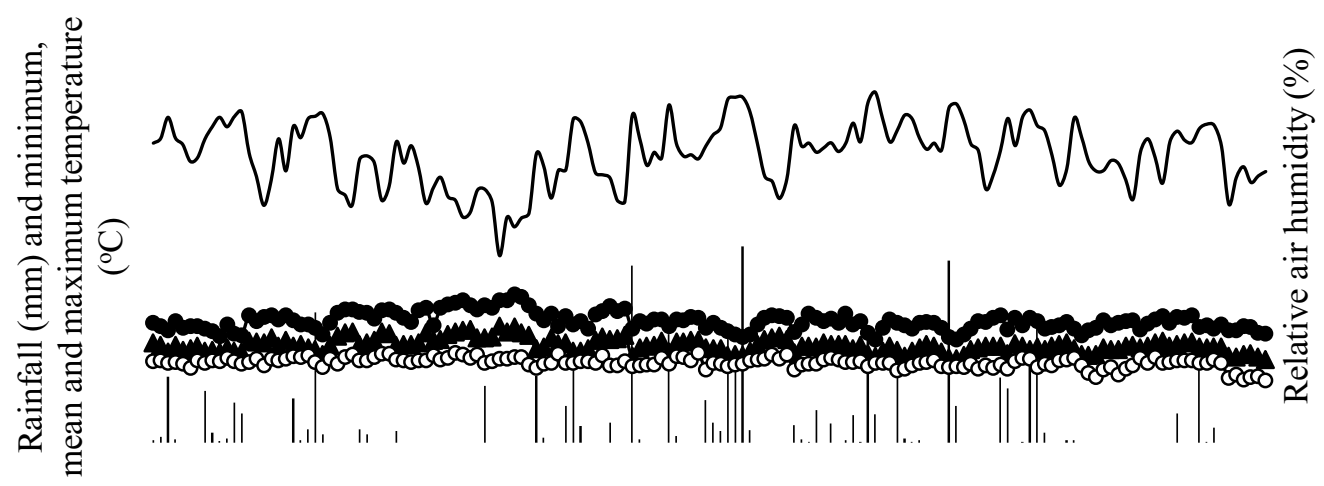

Rainfall $\longrightarrow$ Tmean $\multimap$ Tmax $\multimap$ Tmin $\longrightarrow$ RHmean

Figure 1. Rainfall, relative air humidity (RHmean) and maximum, mean and minimum temperatures (Tmean, Tmax and Tmin) recorded in the meteorological station situated at the Teaching, Research and Extension Farm of the FE/UNESP during the soybean cultivation from December 2014 to April 2015 
is the recommendation of the Embrapa Soybean; 3) Seed inoculated with Azospirillum brasilense at the dose of $200 \mathrm{~mL}$ ha $^{-1}$ (strains Abv5 and Abv6, with guarantee of $2 \times 10^{8} \mathrm{CFU}$ per $\mathrm{mL}$ ) and with Co + Mo application at the above-mentioned dose; 4) Foliar application of Azospirillum brasilense in the V3 stage of soybean, at the previously mentioned dose; 5) Foliar application of Co + Mo in the V3 stage, at the previously mentioned dose; 6) Foliar application of $\mathrm{Co}+\mathrm{Mo}$ along with foliar inoculation of Azospirillum brasilense in the V3 stage, at the above-mentioned doses.

Each plot was composed of seven 5-m-long soybean rows, spaced by $0.45 \mathrm{~m}$, totaling $15.75 \mathrm{~m}^{2}$. The three central rows of each plot, disregarding the single border, were used for evaluations, totaling an effective sampling area of 6.75 $\mathrm{m}^{2}$ plot $^{-1}$

The following variables were evaluated: a) leaf $\mathrm{N}$ content, determined using the methodology described by Malavolta et al. (1997), by collecting the upper third trifoliate of 30 soybean plants, at full flowering, based on the methodology described in Ambrosano et al. (1997); b) hundred-grain weight, determined on a precision scale $(0.01 \mathrm{~g})$, at $13 \%$ (wet basis); c) grain yield, determined through the harvest of plants in the three central rows of each plot. After mechanical threshing, the grains were quantified and the data were transformed to $\mathrm{kg} \mathrm{ha}^{-1}$ at $13 \%$ (wet basis). These results were subjected to analysis of variance (F test) using the Tukey test at 0.05 probability level for the comparison of means.

The economic analysis was made using the structure based on the total operating cost (TOC) of production used by the Institute of Agricultural Economy (IEA), according to Matsunaga et al. (1976), which consists in the sum of all costs: operations, inputs (fertilizers, seeds, pesticides, etc.), labor, machinery and irrigation, referred to as effective operating cost (EOC). Besides the TOC, this study considered other expenses and interest of costs, corresponding to $5 \%$ of the EOC (Matsunaga et al., 1976), thus resulting in the total operating cost (TOC), which was extrapolated to one hectare.

The profitability of the treatments was determined according to Martin et al. (1998), as follows: gross revenue (GR) (in R\$), as the product of the produced amount (number of 60 $\mathrm{kg}$ sacks) and the mean sale price (in $\mathrm{R} \$$ ), and the operating profit (OP), as the difference between the gross revenue and the total operating cost; profitability index (PI), considered as the relationship between the operating profit $(\mathrm{OP})$ and the gross revenue $(\mathrm{GR})$ in percentage.

The analyses considered the prices paid in 2016 (Agrianual, 2015) adjusted to those practiced in commercial plantations in the region of Selvíria, MS, based on the mean of the last 3 agricultural years. In this study, simulations were performed as if each treatment of the experiment represented commercial plantations. To facilitate the discussion, values referring to the yields were transformed to $60 \mathrm{~kg}$ sacks, since this is the basic unit of marketing by the local producers.

\section{Results AND Discussion}

The $\mathrm{N}$ content was influenced by the treatments whose Co + Mo application associated with Azospirillum brasilense inoculation in the seeds and the foliar application of $\mathrm{Co}+\mathrm{Mo}$ promoted higher content of the nutrient in comparison to the foliar application of $A$. brasilense and the non-application of $\mathrm{Co}+\mathrm{Mo}$ and $A$. brasilense (Table 1 ).

This greater $\mathrm{N}$ absorption promoted by $\mathrm{Co}+\mathrm{Mo}$ application associated with the inoculation of $A$. brasilense in the seed reflected in greater plant development (data not shown) and grain filling, which is evidenced by the higher value of hundredgrain weight and, consequently, increase in soybean grain yield in this treatment, in comparison to the foliar application of $A$. brasilense and the control without $\mathrm{Co}+\mathrm{Mo}$ application and inoculation of $A$. brasilense (Table 1). Considering the best treatment cited above, there were increments of 1,007 and 752 $\mathrm{kg} \mathrm{ha}^{-1}$ of grains, equivalent to 18.4 and $13.0 \%$ in relation to the control and the mean of the other treatments, respectively. These results corroborate those of Golo et al. (2009), who report that Co and Mo contribute decisively to the biological $\mathrm{N}_{2}$ fixation (BNF) and those of Hungria et al. (2013), who studied co-inoculation with $A$. brasilense and obtained increment of $16.1 \%$ in soybean grain yield, in comparison to the isolated use of Bradyrhizobium strains.

According to Bárbaro et al. (2009b), the literature reports that bacteria called PGPB (plant growth-promoting bacteria), such as $A$. brasilense, can act in the relationships between rhizobia and leguminous crops, promoting increments in plant growth and grain yield, in the total biologically fixed $\mathrm{N}$, besides improvements in the use of $\mathrm{N}$ obtained by the plant through the symbiosis with rhizobium, corroborating the results found in the present study.

These effects can be due to various mechanisms, which include an anticipation in the BNF of the nodules, increment in the dry matter of the nodules, promotion of occurrence of heterologous nodulation through the increase in the formation of root hairs and secondary roots, with increment in the infection sites, inhibition of phytopathogens and production of phytohormones, besides the influences in the partition of dry matter between roots and shoots (Bárbaro et al., 2009b). In addition, as pondered by Hungria et al. (2013), these effects promoted by the co-inoculation of PGPB and

Table 1. Leaf $\mathrm{N}$ content, hundred-grain weight and grain yield of soybean as a function of the treatments

\begin{tabular}{|c|c|c|c|}
\hline Treatment $^{\#}$ & 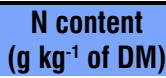 & $\begin{array}{l}\text { Hundred-grain } \\
\text { weight }(\mathrm{g})\end{array}$ & $\begin{array}{c}\text { Grain yield } \\
\left(\mathrm{kg} \mathrm{ha}^{-1}\right)\end{array}$ \\
\hline (1) Control & $48.65 \mathrm{~b}$ & $14.68 \mathrm{~b}$ & $5,550 \mathrm{~b}$ \\
\hline (2) CoMo seed & $50.91 \mathrm{ab}$ & $15.88 \mathrm{ab}$ & $6,083 a b$ \\
\hline (3) CoMo + Azos seed & $56.21 \mathrm{a}$ & $16.10 \mathrm{a}$ & $6,557 \mathrm{a}$ \\
\hline (4) Azos via foliar & $49.00 \mathrm{~b}$ & $14.80 \mathrm{ab}$ & $5,355 b$ \\
\hline (5) CoMo via foliar & $55.95 \mathrm{a}$ & $14.60 \mathrm{~b}$ & $5,685 a b$ \\
\hline (6) $\mathrm{CoMo}+$ Azos foliar & $54.30 \mathrm{ab}$ & $14.88 \mathrm{ab}$ & $5,602 \mathrm{ab}$ \\
\hline Overall Mean & 52.50 & 15.15 & 5,805 \\
\hline CV (\%) & 4.34 & 3.76 & 7.27 \\
\hline LSD (5\%) & 6.46 & 1.31 & 970 \\
\hline
\end{tabular}

Means followed by the same letters in the column do not differ by Tukey at 0.05 probability level. \# The numbers 1, 2, 3, 4, 5 and 6 refer to the treatments: 1) Control (soybean without inoculation of Azospirillum brasilense and without $\mathrm{Co}+\mathrm{Mo}$ application); 2) Soybean seed without inoculation of Azospirillum brasilense and with $\mathrm{Co}+\mathrm{Mo}$ application; 3) Soybean

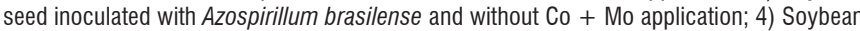
seed without inoculation of Azospirillum brasilense and without $\mathrm{Co}_{0}+\mathrm{Mo}$ application, but with foliar application of Azospirillum brasilense at the soybean V3 stage; 5) Soybean seed without inoculation of Azospirillum brasilense and without $\mathrm{Co}+\mathrm{Mo}$ application, but with foliar application of $\mathrm{Co}+\mathrm{Mo}$ at the $\mathrm{V} 3$ stage; 6 ) Soybean seed without inoculation of Azospirillum brasilense, but with foliar application of $\mathrm{C} 0+$ Mo along with foliar inoculation of Azospirillum brasilense, at the soybean V3 stage 
rhizobium seem to be under the influence of specific signals between the involved bacterial genotypes and the host plant genotype, which requires more studies on the response of the co-inoculation as a function of the genotypes, in order to obtain more-responsive genotypes.

Table 2 shows the structure of the total operating cost (TOC) of the soybean crop, describing the control treatment, in one hectare. This model of TOC structure was used in all treatments.

The initial investments with soil tillage and liming were not considered in this study, since these practices were not performed, especially because the area had been under no tillage system for more than ten years when the experiment was installed, thus contributing to the reduction of the initial costs with the planting of the soybean crop.

The expenses with mechanized operations and inputs, which constitute the effective operating cost (EOC), were $1,668.35 \mathrm{ha}^{-1}$ and the total operating cost (TOC) was R\$

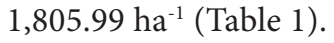

In the operations that constitute the EOC, the costs with irrigation stand out, totaling $21 \%$ of the expenses, because, to obtain the high grain yields observed in the cultivation period, besides the characteristics of the studied region (Cerrado), it was necessary to adopt this technology (irrigation). However, for the expenses with inputs, fertilizers and pesticides stand out, being responsible for 36.22 and $10.51 \%$ of the EOC, respectively (Table 2). Probably, this occurred due to the large requirement for nutrients by the soybean crop, which demands a considerable amount of fertilizer for high grain yields, besides the need of desiccation and control of weeds and pathogens.

In general, the expenses with mechanized operations, followed by fertilizers, were the highest ones, corresponding to 42.6 and $33.5 \%$ of the TOC, respectively (Table 2 ). It should be pointed out that, with the application of $\mathrm{Co}+\mathrm{Mo}$ and with the inoculation of $A$. brasilense, there is an increase in the percentage of expenses in relation to the TOC. The costs with the use of $\mathrm{Co}+\mathrm{Mo}$ and with inoculation of $A$. brasilense, individually or combined, corresponded to $0.6,1.1$ and $1.7 \%$ of the TOC, respectively.

As to the TOC and the grain yield of the treatments (Table 3 ), the highest value of TOC refers to the treatment with inoculation of $A$. brasilense and foliar application of $\mathrm{Co}+$ Mo, whereas the lowest TOC value corresponds to the control treatment, i.e., only with the inoculation of Bradyrhizobium strains. However, it is important to highlight that, to obtain the highest soybean grain yields (Table 1), both the Co + Mo application and the inoculation of $A$. brasilense were important to increase BNF efficiency, since there was an increment in the leaf $\mathrm{N}$ content.

As to grain yield, the application of $\mathrm{Co}+\mathrm{Mo}$ and the co-inoculation of the soybean crop with A. brasilense via seeds stand out, which led to mean yield of 109 sacks of 60 $\mathrm{kg}$, approximately 17 sacks of grains more than the control (Table 3).

Regarding the gross revenues per hectare (Table 3 ) obtained in the combinations of the treatments for the soybean crop,

Table 3. Total operating cost (TOC), grain yield (GY) and gross revenue (GR) of the soybean crop as a function of combination of treatments

\begin{tabular}{lccc}
\hline \multicolumn{1}{c}{ Treatment } & TOC & GY & GR \\
Control & R\$ & sc $\mathbf{6 0 ~ k g ~ h a - 1}$ & R\$ \\
CoMo seed & $1,805.99$ & 92.50 & $5,735.00$ \\
A. brasilense + CoMo seed & $1,817.87$ & 101.38 & $6,285.77$ \\
A. brasilense foliar & $1,839.52$ & 109.28 & $6,775.57$ \\
CoMo foliar & $1,882.84$ & 89.25 & $5,533.50$ \\
A. brasilense + CoMo foliar & $1,817.87$ & 94.75 & $5,874.50$ \\
Mean & $1,894.73$ & 93.37 & $5,788.73$ \\
\hline
\end{tabular}

${ }^{* *}$ Soybean marketing price $-\mathrm{R} \$ 62.00 \mathrm{sc}$

Table 2. Estimate of total operating cost of soybean for the control treatment calculated for one hectare (ha)

\begin{tabular}{|c|c|c|c|c|c|}
\hline \multirow{3}{*}{ Description } & \multicolumn{5}{|c|}{ Production cost } \\
\hline & \multirow{2}{*}{ Specification ${ }^{1}$} & \multirow{2}{*}{$\mathrm{N}^{0}$ times } & \multirow{2}{*}{ Coefficient } & Unitary value & Total value \\
\hline & & & & \multicolumn{2}{|c|}{$(\mathrm{R} \$)$} \\
\hline \multicolumn{6}{|l|}{ A - Mechanized operations } \\
\hline Desiccation & HM & 1.00 & 0.50 & 85.00 & 42.50 \\
\hline Mowing (triton) & $\mathrm{HM}$ & 1.00 & 0.50 & 85.00 & 42.50 \\
\hline Sowing & HM & 1.00 & 1.00 & 110.00 & 110.00 \\
\hline Spraying & $\mathrm{HM}$ & 3.00 & 0.60 & 85.00 & 153.00 \\
\hline Harvest & HM & 1.00 & 0.60 & 118.00 & 70.80 \\
\hline Irrigation (pivot) & $\mathrm{mm}$ & 1.00 & 140.00 & 2.50 & 350.00 \\
\hline Subtotal A & & & & & 768.80 \\
\hline \multicolumn{6}{|l|}{ B - Inputs } \\
\hline Fertilizer 04-20-20 & t & 1.00 & 0.40 & $1,510.71$ & 604.28 \\
\hline Inoculant (B. elkanii and B. japonicum) & $100 \mathrm{~mL}$ & 1.00 & 2.00 & 10.00 & 20.00 \\
\hline Soybean seeds & sc $50 \mathrm{~kg}$ & 1.00 & 1.00 & 100.00 & 100.00 \\
\hline Herbicide Glyphosate & $\mathrm{L}$ & 1.00 & 4.00 & 14.51 & 58.04 \\
\hline Herbicide 2,4-D & $\mathrm{L}$ & 1.00 & 1.00 & 13.24 & 13.24 \\
\hline Herbicide chlorimuron & $\mathrm{kg}$ & 1.00 & 0.03 & 146.68 & 4.40 \\
\hline Fungicide seed treatment carbendazim & $\mathrm{L}$ & 1.00 & 0.05 & 45.57 & 2.28 \\
\hline Insecticide seed treatment thiamethoxam & $\mathrm{L}$ & 1.00 & 0.10 & 407.68 & 40.77 \\
\hline Fungicide azoxystrobin + cyproconazole & L & 1.00 & 0.30 & 150.89 & 45.27 \\
\hline Insecticide methomyl & $\mathrm{L}$ & 1.00 & 0.50 & 22.54 & 11.27 \\
\hline Subtotal B & & & & & 899.55 \\
\hline Effective operating cost (EOC) & & & & \multicolumn{2}{|c|}{$1,668.35$} \\
\hline Other expenses & & & & \multicolumn{2}{|c|}{83.42} \\
\hline Interest of costs & & & & \multicolumn{2}{|c|}{54.22} \\
\hline Total operating cost (TOC) & & & & \multicolumn{2}{|c|}{$1,805.99$} \\
\hline
\end{tabular}


it was observed that, for a constant price of the soybean, the gross revenues of the treatments followed the same trend of the yields (Table 3), i.e., the increments in the revenue occur through the increments in grain yield. This result in agreement with Silva et al. (2007) and Duete et al. (2009), who claim that yield is an essential factor to guarantee good profitability to the producer. According to Duete et al. (2009), even in regions in which the producer obtains good prices in the marketing of grains, if the yield is low, the profitability is compromised. Thus, the investment in management practices, such as balanced fertilization and inoculation with PGPB, increase grain yield and the gross margin of the crops, regardless of the site.

The operating profit (OP) was positive for all treatments (Table 4), regardless of the application of $\mathrm{Co}+\mathrm{Mo}$ and inoculation with Azospirillum brasilense. The highest $\mathrm{OP}$ was obtained with the application of $\mathrm{Co}+$ Mo with inoculation of A. brasilense via seeds ( $\mathrm{R} \$ 4,936.04)$. In the absence of $\mathrm{Co}+\mathrm{Mo}$ application and inoculation with $A$. brasilense, which would cause reduction in the costs, with possibility of increase in OP, if good yields were obtained, soybean cultivation would be viable, although with a decrease of $\mathrm{R} \$ 1,007.03 \mathrm{ha}^{-1}$ in the profit, corresponding to a reduction of $20.4 \%$ in the profitability.

As observed for OP, the treatment that led to the highest PI was the application of $\mathrm{Co}+\mathrm{Mo}$ associated with the inoculation of A. brasilense (72.85\%), being $4.34 \%$ higher in comparison to the control (Table 4), reinforcing the importance of using Co + Mo and co-inoculation of $A$. brasilense to obtain high grain yields with financial return.

The obtained economic results validate what is pondered by Hungria et al. (2013). These authors claim that microbial inoculants are very inexpensive and considering only the soybean crop, it is estimated that Brazil saves, per year, about US\$ 7 billion with BNF. Therefore, due to the better nutrition of the plant not only with $\mathrm{N}$ and the increase in soybean yield, the tendency is that the co-inoculation with A. brasilense will increase in Brazil, especially because it is a low-cost and low-investment technique, with easy application and use, nonpolluting and also it fits in the currently aimed sustainable concept.

Table 4. Operating profit (OP) and profitability index (PI) of the soybean crop as a function of the treatments

\begin{tabular}{lcc}
\hline \multicolumn{1}{c}{ Treatment } & OP & PI \\
Control & $3,929.01$ & $\mathbf{( \% )}$ \\
CoMo seed & $4,467.89$ & 68.51 \\
A. brasilense + CoMo seed & $4,936.04$ & 71.08 \\
A. brasilense foliar & $3,650.66$ & 65.85 \\
CoMo foliar & $4,056.63$ & 69.05 \\
A. brasilense + CoMo foliar & $3,894.00$ & 67.27 \\
Mean & $4,155.71$ & 69.12 \\
\hline
\end{tabular}

\section{Conclusions}

1. Co + Mo application via seeds, associated with the inoculation of $A$. brasilense in the seeds, promoted the highest leaf $\mathrm{N}$ content, hundred-grain weight and grain yield in the soybean crop.

2. The co-inoculation with $A$. brasilense and $\mathrm{Co}+\mathrm{Mo}$ application via seeds promote higher profitability with the soybean crop, being technically and economically viable.

\section{Literature Cited}

Agrianual. Anuário da Agricultura Brasileira. São Paulo: AgraFNP. 2015. 482p.

Ambrosano, E. J.; Tanaka, R. T.; Mascarenhas, H. A. A.; Raij, B. van; Quaggio, J. A.; Cantarella, H. Leguminosas e oleaginosas. In: Raij, B. van; Cantarella, H.; Quaggio, J. A.; Furlani, A. M. C. Recomendações de calagem e adubação para o Estado de São Paulo. Campinas: IAC, 1997. p.187-203. Boletim técnico, 100

Bárbaro, I. M.; Centurion, M. A. P. C.; Gavioli, E. A.; Sarti, D. G. P. S.; Barbaro Júnior, L. S.; Ticelli, M.; Miguel, F. B. Análise de cultivares de soja em resposta à inoculação e aplicação de cobalto e molibdênio. Revista Ceres, v.56, p.342-349, 2009a.

Bárbaro, I. M.; Machado, P. C.; Bárbaro Júnior, L. S.; Ticelli, M.; Miguel, F. B.; Silva, J. A. A. da. Produtividade da soja em resposta á inoculação padrão e co-inoculação. Colloquium Agrariae, v.5, p.1-7, 2009b. https://doi.org/10.5747/ca.2009.v05.n1.a0040

Bulegon, L. G.; Rampim, L.; Klein, J.; Kestring, D.; Guimarães, V. F.; Battistus, A. G.; Inagaki, A. M. Componentes de produção e produtividade da cultura da soja submetida à inoculação de Bradyrhizobium e Azospirillum. Revista Terra Latinoamericana, v.34, p.169-176, 2016.

Dourado Neto, D.; Dario, G. J. A.; Martin, T. N.; Silva, M. R. da; Pavinato, P. S.; Habitzreiter, T. L. Adubação mineral com cobalto e molibdênio na cultura da soja. Semina: Ciências Agrárias, v.33, p.2741-2752, 2012. https://doi.org/10.5433/16790359.2012v33Supl1p2741

Duete, R. R. C.; Muraoka, T.; Silva, E.; Trevelin, P.; Ambrosano, E. J. Viabilidade econômica de doses e parcelamentos da adubação nitrogenada na cultura do milho em Latossolo Vermelho Eutrófico. Acta Scientiarum Agronomy, v.31, p.175-181, 2009. https://doi.org/10.4025/actasciagron.v31i1.6646

EMBRAPA - Empresa Brasileira de Pesquisa Agropecuária. Centro Nacional de Pesquisa de Solos. Sistema brasileiro de classificação de solos. 3.ed. Brasília: EMBRAPA, 2013. 353p.

Figueiredo, M. V. B.; Martinez, C. R.; Burity, H. A.; Chanway, C. P. Plant growth-promoting rhizobacteria for improving nodulation and nitrogen fixation in the common bean (Phaseolus vulgaris L.). World Journal of Microbiology and Biotechnology, v.24, p.11871193, 2008. https://doi.org/10.1007/s11274-007-9591-4

Galindo, F. S.; Teixeira Filho, M. C. M.; Buzetti, S.; Santini, J. M. K.; Alves, C. J.; Nogueira, L. M.; Ludkiewicz, M. G. Z.; Andreotti, M.; Bellote, J. L. M. Corn yield and foliar diagnosis affected by nitrogen fertilization and inoculation with Azospirillum brasilense. Revista Brasileira de Ciência do Solo, v.40, p.1-18, 2016. https:// doi.org/10.1590/18069657rbcs20150364

Golo, A. L.; Kappes, C.; Carvalho, M. A. C.; Yamashita, O. M. Qualidade das sementes de soja com a aplicação de diferentes doses de molibdênio e cobalto. Revista Brasileira de Sementes, v.31, p.40-49, 2009. https://doi.org/10.1590/S0101-31222009000100005

Hungria, M.; Campo, R. J.: Souza, E. M.; Pedrosa, F. O. Inoculation with selected strains of Azospirillum brasilense and A. lipoferum improves yields of maize and wheat in Brazil. Plant and Soil, v.331, p.413-425, 2010. https://doi.org/10.1007/s11104-009-0262-0

Hungria, M.; Nogueira, M. A.; Araujo, R. S. Co-inoculation of soybeans and common beans with rhizobia and azospirilla: strategies to improve sustainability. Biology and Fertility of Soils, v.49, p791-801, 2013. https://doi.org/10.1007/s00374-012-0771-5 
Ignácio, V. L.; Nava, I. A.; Malavasi, M. M. Gris, E. P. Influence of foliar fertilization with manganese on germination, vigor and storage time of RR soybean seeds. Revista Ceres, v.62, p.46-452, 2015. https://doi.org/10.1590/0034-737X201562050004

Malavolta, E.; Vitti, G. C.; Oliveira, S. A. Avaliação do estado nutricional das plantas: Princípios e aplicações. 2.ed. Piracicaba: Associação Brasileira para Pesquisa da Potassa e do Fosfato, 1997. 319p.

Martin, N. B.; Serra, R.; Oliveira, M. D. M.; Ângelo, J. A.; Okawa, H. Sistema integrado de custos agropecuários - "Custagri". Informações Econômicas, v.28, p.7-28, 1998.

Matsunaga, M.; Bemelmans, P. F.; Toledo, P. N. E.; Dulley, R. D.; Okawa, H.; Pedroso, I. A. Metodologia de custo de produção utilizada pelo IEA. Agricultura em São Paulo, v.23, p.123-139, 1976.

Raij, B. van; Andrade, J. C.; Cantarella, H.; Quaggio, J. A. Análise química para avaliação da fertilidade de solos tropicais. Campinas: IAC, 2001. 285p.
Rodrigues, A. C.; Antunes, J. E. L.; Medeiros, V. V. de; Barros, B. G. F.; Figueiredo, M. D. V. B. Resposta da co-inoculação de bactérias promotoras de crescimento em plantas e Bradyrhizobium sp. em caupi. Bioscience Journal, v.28, p.196-202, 2012.

Silva, E. C.; Muraoka, T.; Monteiro, R. O. C.; Buzetti, S. Análise econômica da adubação nitrogenada no milho sob plantio direto em sucessão a plantas de cobertura em Latossolo Vermelho. Acta Scientiarum. Agronomy, v.29, p.445-452, 2007. https://doi. org/10.4025/actasciagron.v29i4.395

Vieira Neto, S. A.; Pires, F. R.; Menezes, C. C. E. D.; Menezes, J. F. S.; Silva, A. G. D.; Silva, G. P.; Assis, R. L. D. Formas de aplicação de inoculante e seus efeitos sobre a nodulação da soja. Revista Brasileira de Ciência do Solo, v.32, p.861-870, 2008. https://doi. org/10.1590/S0100-06832008000200040

Zilli, J. É.; Marson, L. C.; Marson, B. F.; Gianluppi, V.; Campo, R. J.; Hungria, M. Inoculação de Bradyrhizobium em soja por pulverização em cobertura. Pesquisa Agropecuária Brasileira, v.43, p.541-544, 2008. https://doi.org/10.1590/S0100-204X2008000400014 